\title{
Kecenderungan Terjangkit TB Paru Pada Orang Dengan Status Gizi Kurus
}

\author{
Aina'ul Mardliyyatun Nisa \\ Institut Ilmu Kesehatan Surya Mitra Husada \\ aina9919@gmail.com
}

\begin{abstract}
ABSTRAK
Tuberculosis adalah penyakit infeksi menular yang disebabkan oleh Mycobacterium tuberculosi yang menyerang paru-paru dan hampir seluruh organ tubuh lainnya (Nurarif, 2015). Berdasarkan data Riskesdas tahun 2018 di Indonesia sendiri tercatat $0,42 \%$ penduduknya terdiagnosis penyakit TBC. Beberapa faktor yang mempengaruhi seseorang dapat terjangkit TBC seperti status sosial ekonomi, status gizi, umur, jenis kelamin, pendidikan, faktor lingkungan dan kebiasaan merokok (Kemenkes RI, 2014). Orang dengan status gizi yang buruk lebih mudah untuk terinfeksi dan terjangkit TBC (Indah, 2018). Status gizi memiliki peran yang penting dalam penyebaran dan penyembuhan penyakit TBC paru. Orang dengan status gizi kurus memiliki kecenderungan yang lebih tinggi untuk terjangkit TBC paru.

Keyword: TB Paru, Status Gizi
\end{abstract}

\section{LATAR BELAKANG}

Tuberculosis adalah penyakit infeksi menular yang disebabkan oleh Mycobacterium tuberculosi yang menyerang paru-paru dan hampir seluruh organ tubuh lainnya (Nurarif, 2015). Menurut data WHO tahun 2018 Indonesia menempati posisi ketiga dengan penderita TBC terbanyak di dunia setelah China dan India (lifestyle.okezone.com, 2018).

Penyakit TBC menjadi salah satu yang sedang digalakan upaya prefentif dan kuratif bagi penderitanya. Berdasarkan data Riskesdas tahun 2018 di Indonesia sendiri tercatat $0,42 \%$ penduduknya terdiagnosis penyakit TBC. Angka kejadian TBC tertinggi di Indonesia berada di provinsi Papua dengan prevalensi 0,77\%, kemudian provinsi Banten 
dengan prevalensi $0,76 \%$, kemudian provinsi Jawa Barat dengan prevalensi $0,63 \%$.

Beberapa faktor yang mempengaruhi seseorang dapat terjangkit TBC seperti status sosial ekonomi, status gizi, umur, jenis kelamin, pendidikan, faktor lingkungan dan kebiasaan merokok (Kemenkes RI, 2014). Gizi merupakan salah satu faktor penting yang mempengaruhi kekebalan tubuh seseorang. Jika status gizi tidak optimal maka status kesehatan juga dapat menurun. Keadaan kekuranga gizi menjadikan seseorang rentan untuk mengalami suatu penyakit salah satunya TB Paru.

\section{KASUS/MASALAH}

Bagaimana kecenderungan terjangkit TB Paru pada orang dengan status gizi kurus?

\section{TINJAUAN PUSTAKA}

\section{Tuberculosis Paru}

Tuberculosis adalah penyakit infeksi menular yang disebabkan oleh Mycobacterium tuberculosi yang menyerang paru-paru dan hampir seluruh organ tubuh lainnya (Nurarif, 2015). Bakteri tuberculosis paling banyak menular melalui inhalasi droplet yang berasal dari orang yang terinfeksi bekteri tersebut. Selain melalui droplet penularan juga bisa melalui saluran pencernaan dan luka terbuka pada kulit (Nurarif, 2015).

Tanda dan gejala dari TBC paru sendiri meliputi; batuk berdahak lebih dari dua minggu atau lebih, batuk diikuti gejala tambahan berupa dahak bercampur darah, batuk darah, sesak nafas, badan lemas, nafsu makan 
turun, berat badan menurun, malaise, berkerinngat malam hari tanpa kegiatan fisik, demam meriang lebih dari satu bulan (Indah, 2018).

Beberapa faktor yang mempengaruhi seseorang dapat terjangkit TBC seperti status sosial ekonomi, status gizi, umur, jenis kelamin, pendidikan, faktor lingkungan dan kebiasaan merokok (Kemenkes RI, 2014).

Faktor yang mempengaruhi penyakit tuberculosis paru sendiri bermacam-macam dalam jurnal yang ditulis oleh Nurjana tahun 2015 menyebutkan beberapa faktor risiko terjadinya $\mathrm{Tb}$ paru pada usia produktif adalah pendidikan, indeks kepemilikan, bahan bakar memasak, kondisi ruangan dan perilaku merokok. Selain itu menurut Indah tahun 2018 menyebutkan faktor risiko yang mempengaruhi TBC disebakan karena menurunnya daya tahan tubuh seseorang. Dalam perspektif epidemiologi yang melihat penyakit merupakan interaksi antara tiga komponen yaitu host, agent dan envorintement dapat disimpulkan bahwa pada sisi host akan rentan terhadap Mycobacterium tuberculosis jika host memiliki daya tahan tubuh yang lemah. Pengidap HIV AIDS atau orang dengan status gizi yang buruk lebih mudah untuk terinfeksi dan terjangkit TBC.

\section{Status Gizi}

Gizi adalah ikatan kimia yang diperlukan tubuh untuk menjalankan fungsinya (Banowati, 2014). Untuk mencapai kesehatan yang optimal maka diperlukan makanan yang mengandung gizi. Makanan yang mengandung gizi diperlukan untuk menjaga dan meningkatkan kesehatan 
zat-zat gizi dikelompokan menjadi lima yaitu protein, lemak, karbohidrat, vitamin dan mineral.

Status gizi adalah keadaan tubuh sebagai akibat konsumsi makanan Dan penggunaan zat gizi (Banowati, 2014). Beberapa macam cara yang sering digunakan untuk mengukur status gizi di masyarakat pertama dengan berat badan per umur, tinggi badan menurut umur, berat badan menurut tinggi, lingkar lengan atas menurut umur dan dengan menggunakan Indeks masa tubuh (Notoatmodjo, 2011).

Indeks masa tubuh merupakan pengukuran status gizi orang dewasa dengan melakukan penghitungan berat badan kwadrat dalam kilogram dibagi tinggi badan dalam meter. Hasil perhitungan dengan formula ini akan mengindikasi status gizi dengan klasifikasi: kurus (gizi kurang) jika IMT < 18, normal (gizi baik) jika IMT 18-24, gemuk jika IMT 25-30 dan obesitas jika IMT lebih dari 30 (Notoatmodjo, 2011).

Dalam Notoatmodjo tahun 2011 disebutkan bahwa bila tubuh berada dalam tingkat kesehatan gizi optimum di mana jaringan jenuh oleh semua zat gizi maka dalam kondisi demikian tubuh terbebas dari penyakit dan mempunyai daya tahan tubuh setinggi-tingginya. Apabila konsumsi gizi makanan pada seseorang tidak seimbang maka akan terjadi kesalahan akibat gizi.

\section{PEMBAHASAN}

Tuberculosis merupakan salah satu penyakit menular yang masih menjadi problem di Indonesia maupun di dunia. Penderitanya sendiri 
bertambah tiap tahunnya. Menurut kemenkes RI tahun 2014 disebutkan bahwa beberapa faktor yang mempengaruhi seseorang dapat terjangkit TBC seperti status sosial ekonomi, status gizi, umur, jenis kelamin, pendidikan, faktor lingkungan dan kebiasaan merokok.

Berdasarkan penelitian yang dilakukan oleh Wokas dkk pada tahun 2015 menyebutkan bahwa tidak terdapat hubungan antara status gizi dengan hasil pemerikasaan sputum BTA dan gambaran rontgen paru pada pasien tuberculosis. Status gizi merupakan hal yang mempengaruhi daya tahan tubuh seseorang jika seseorang memiliki status gizi rendah kemungkinan terjadinya penyakit juga tinggi sesuai dalam Notoatmodjo tahun 2011 disebutkan bahwa bila tubuh berada dalam tingkat kesehatan gizi optimum di mana jaringan jenuh oleh semua zat gizi maka dalam kondisi demikian tubuh terbebas dari penyakit dan mempunyai daya tahan tubuh setinggi-tingginya. Menurut penulis hal tersebut kemuungkinan karena setiap orang memiliki ketahanan tubuh yang berbeda-beda walaupun memiliki status gizi yang kurus

Dalam penelitian yang dilakukan oleh yusuf dan nurlaeli tahun 2017 hasil penelitian yang telah dilakukan tentang Hubungan Status Gizi Dengan Kejadian TB Paru Di Balai Pengobatan Penyakit Paru - Paru (BP4) Lubuk Alung Sumatera Barat Tahun 2017 menyebutkan bahwa adanya hubungan antara status gizi dengan kejdian Tb paru dari 50 sample didapatkan $44 \%$ responden memiliki status gizi yang kurus dan $40 \%$ responden mengalami tuberculosis paru. Hal tersebut sesuai dengan teori yang menyebutkan bahwa orang dengan status gizi yang buruk lebih mudah untuk terinfeksi dan 
terjangkit TBC (Indah, 2018). Meneurut penulis penelitian ini lebih sesuai dengan teori tentang agent, host dan envorintmen dan lebih dekat dengan teori-teori lainnya.

Berdasarkan penelitian yang dilakukan oleh Murtantiningsih dan Wahyono tahun 2010 menyebutkan bahwa faktor yang mempengaruhi kesembuhan penderita TB paru adalah status gizi, pendapatan dan keteraturan berobat. Hal ini juga sesuai dengan penelitian lain yang dilakukan oleh Kusumaningroh dkk tahun 2018 yang menyebutkan bahwa adanya hubungan aktifitas fisik dan fase pengobatan TB dengan status gizi.

Dari berbagai sumber di atas menampilkan bahwa status gizi memiliki peran yang penting dalam penyebaran dan penyembuhan penyakit TBC paru. Selain itu dari berbagai jurnal di atas status gizi kurus memiliki kecenderungan untuk terjangkit TBC paru dengan lebih mudah. Status gizi memiliki peran yang penting dalam memperoleh kesehatan optimal. Adanya perbedaan hasil penelitan di atas kemungkinan dikarenakan lokasi penelitian yang berbeda, responden yang berbeda dan kemungkinan fase pengobatan dan fase TBC paru yang berbeda.

\section{KESIMPULAN}

Dari berbagai jurnal dan teori di atas dapat disimpulakn bahwa orang dengan status gizi kurus memiliki kecenderungan yang lebih tinggi untuk terjangkit TBC paru. 


\section{DAFTAR PUSTAKA}

Badan Penelitian dan Pengembangan Kesehatan Kementrian Kesehatan RI. 2019. Laporan Nasional Riskesdas 2018. Jakarta: Lembaga Penerbit Balitbangkes.

Banowati, L. 2014. Ilmu Gizi Dasar.Sleman: Deeppublish Publisher. Indah, M. 2018. Infodatin Tuberkulosis 2018. Jakarta: Kemenkes RI.

Kemenkes RI. 2014. Pedoman Nasional Pengendalian Tuberkulosis. Jakarta: Kemenkes RI.

Kusumaningroh. 2018. Hubungan Aktivitas Fisik dan Fase Pengobatan TB Dengan Stats Gizi Pada Pasien TB Paru. Jurnal Ners dan Kebidanan, Vol. 5 No 1, 1-7.

Murtaningsih dan Wahyono, B. 2010. Faktor-faktr Yang Berhubungan Dengan Kesembuhan Penderita Tuberkulosis Paru. Jurnal Kesehatan Masyarakat, Kemas 6 (1), 44-50.

Notoatmodjo, S. 2011. Kesehatan Masyarakat Ilmu dan Seni. Jakarta: Rineka Cipta.

Nurarif, A.H. 2015. Aplikasi Asuhan Keperawatan Berdasarkan Diagnosa Medis dan Nanda Nic-Noc edisi Revisi Jilid 3. Jogjakarta: Mediaction Publishingg Jogjakarta.

Nurjana, M.A. 2015. Faktor Risiko Terjadinya Tuberculosis Paru Usia Produktif (15-49 tahun) di Indonesia. Media Litbangkes, Vol 25 No. 3, September 2015, 165-170. 
Okezone.com. 2018. Kasus TBC di Indonesia tertinggi Ketiga di Dunia. https://lifestyle.okezone.com/read/2018/11/22/481/1981229/kasus-tbcdi-indonesia-tertinggi-ketiga-di-dunia diakses 28 Desember 2019.

Sodik, M. A. (2018). Merokok \& Bahayanya.

Wokas, dkk. 2015. Hubungan antara status gizi, sputum BTA, Gambaran Rontgen Paru Pada Pasien Tuberkulosis. Jurnal e-Clinic (eCl), Vol. 3 No 1, 298-305.

Yusuf dan Nurleli. 2017. Hubungan Status Gizi dan Kejadian TB Paru. Jurnal Kesehatan Saintika Meditiry, Vol 1 No. 1, 35-44. 